\title{
Bird community structure as a function of habitat heterogeneity: A case of Mardi Himal, Central Nepal
}

\author{
NARESH PANDEY ${ }^{1}$, LAXMAN KHANAL ${ }^{1, \bullet}$, NEETI CHAPAGAIN ${ }^{2}$, K. DEEPAK SINGH $^{1}$, \\ BISHNU P. BHATTARAI ${ }^{1}$, MUKESH KUMAR CHALISE ${ }^{1}$ \\ ${ }^{1}$ Central Department of Zoology, Institute of Science and Technology, Tribhuvan University. Kirtipur, Kathmandu 44618, Nepal \\ Tel.: +977-9851084825, `email: 1khanal@cdztu.edu.np \\ ${ }^{2}$ Department of Zoology, Amrit Science Campus, Tribhuvan University. Amrit Marg, Thamel, Kathmandu 44600, Nepal
}

Manuscript received: 17 October 2020. Revision accepted: 22 December 2020.

\begin{abstract}
Pandey N, Khanal L, Chapagain N, Singh KD, Bhattarai BP, Chalise MK. 2021. Bird community structure as a function of habitat heterogeneity: A case of Mardi Himal, Central Nepal. Biodiversitas 22: 262-271. Community structure of birds at different habitat types is underexplored in the montane environment of the central Himalaya. Therefore, this study explored bird community structure in different habitat types in Mardi Himal of the Annapurna Conservation Area, central Nepal, and tested association of different feeding guilds with the habitats. Data on the avian richness and abundance were collected in the winter and the summer of 2019 by point count method along the elevational gradient in every $100 \mathrm{~m}$ rise and analyzed using ordination methods. A total of 673 individuals of 112 bird species from 35 families under 13 orders were recorded. Among the observed orders and families, the order Passeriformes (77 species) and family Muscicapidae (16 species) were the most dominant. A linear species accumulation curve was obtained in both seasons. Species richness and abundance were found higher at forest edges of mid-elevations and insectivores were the most abundant birds. Frugivorous and carnivorous birds showed no specific association with habitat types, whereas, insectivores and omnivores were more abundant in pastureland and forest, respectively. Our results revealed that the community composition of birds varies with the habitat types and their feeding specialization is one of the major determinants.
\end{abstract}

Keywords: Bird community, elevation, feeding guilds, habitat, species accumulation curve

\section{INTRODUCTION}

Spatiotemporal distribution of some key environmental resources governs abundance of bird species (McCain 2009). Therefore, studies have attempted to study factors that affect bird abundance and distribution at spatial and temporal scales (He et al. 2019; Pandey et al. 2020). Studies have shown association of particular bird species to the specific habitat (Brawn et al. 2001; Seymour and Simmons 2008). Due to birds' rapid response to changing habitat (Cresswell et al. 2007), they are good indicator of habitat quality, productivity, and stability (Vallecillo et al. 2016) and hence they are used as surrogates for assessing the impact of habitat changes (Chettri et al. 2001; Veraart et al. 2004). Basic information about explanatory factors of fluctuating bird population (Norvell et al. 2003) and information for conservation and management of threatened species (Sauer and Link 2002) are provided by monitoring species abundance, habitat preference, and correlations between species abundance and habitat.

Seasonal change in climate of a mountain ecosystem affects the bird species richness, composition and abundance (Blake and Loiselle 2000; Shiu and Lee 2003; Shoo et al. 2005). Changes in abiotic and biotic factors force the bird species to ascend and descend avoiding the harsh environmental conditions (Amani et al. 2018). Seasonal change affects food, water, and cover availability of bird population, so, they shift/migrate to habitat/areas with surplus resources to maximize breeding success and to minimize high physiological risk and low resource availability (Beuel et al. 2016; Girma et al. 2017; Kawamura et al. 2019), which ultimately brings change in seasonal site-wise richness pattern.

Annapurna Conservation Area (ACA) is one of the Important Bird and Biodiversity Areas (IBAs) and a global hotspot of bird diversity (BCN 2011; Pandey et al. 2020). It is one of the largest protected areas of Nepal covering an area of 7629 square kilometers. Its area stretches from the subtropical lowlands and lush temperate rhododendron forest in the south to dry alpine forest in the north. Apart from having spectacular landscapes, the ACA is known as a treasure house to 22 different forest types, 1226 species of flowering plants, 105 mammals, 518 birds, 40 reptiles, and 23 amphibians (NTNC-ACAP 2020). A total of 518 bird species representing 14 orders and 52 families were recorded in ACA (Inskipp and Inskipp 2003). Despite having large avian species richness, studies on avian species in the ACA are limited to the checklist or basic ecology of the single or few species.

Mardi Himal trek is a newly established (officially opened in $2012 \mathrm{AD}$ ) trekking trail that lies in the southwestern side of the Annapurna mountain range in the ACA (Pandey et al. 2020). To date, research along this route to exhibit the avian species distribution and abundance on different habitat types is lacking. In order to fill this gap, which ultimately aids the conservation of species and 
proper management of the mountain trail with potential anthropogenic pressure, this study was carried out in the Mardi Himal aiming to assess i) avian community structure ii) richness and abundance in different habitat types, and iii) habitat association of different feeding guilds of the birds.

\section{MATERIALS AND METHODS}

\section{Study area}

The central one-third stretch of the Himalayan range is the Nepal Himalaya. Mardi Himal, the southern summit (5578 $\mathrm{m}$ asl) of Annapurna mountain range, has a newly open trekking trail with panoramic view of Annapurna, Dhaulagiri, Macchapuchre, and Manaslu mountains that are the major attraction of this trekking trail. The trail has diverse vegetation types ranging from sub-tropical to subalpine grassland. The lowest elevational point (P1, $1030 \mathrm{~m}$ asl) of the study was the confluence site of Seti Gandaki and Mardi River; and the highest point (P21, $3050 \mathrm{~m}$ asl) was the Low-Camp of Mardi Himal (Figure 1).

Vegetation varies along the trekking trail. Lower elevational point count sites (around $1100 \mathrm{~m}$ asl), lies on upper sub-tropical bioclimatic zone which is characterized by presence of vegetation like Schima wallichii, Castanopsis indica, Alnus nepalensis, Holarrhena antidysenterica, etc. Vegetation found in the middle elevation (around $1600 \mathrm{~m}$ ) area is Santalum spp. (dominant), Alnus nepalensis, Juglans regia, Prunus sp., Ficus auriculata, Prunus spp. etc. In the high elevational point, there is a dense forest of Osmanthus spp., Rhododendron arboreum, Juniperus squamat, Quercus semecarpifolia, etc. Treeline ends and meadows with shrubs are found after this elevation. The landscape changes quite abruptly into a rugged high mountain landscape.

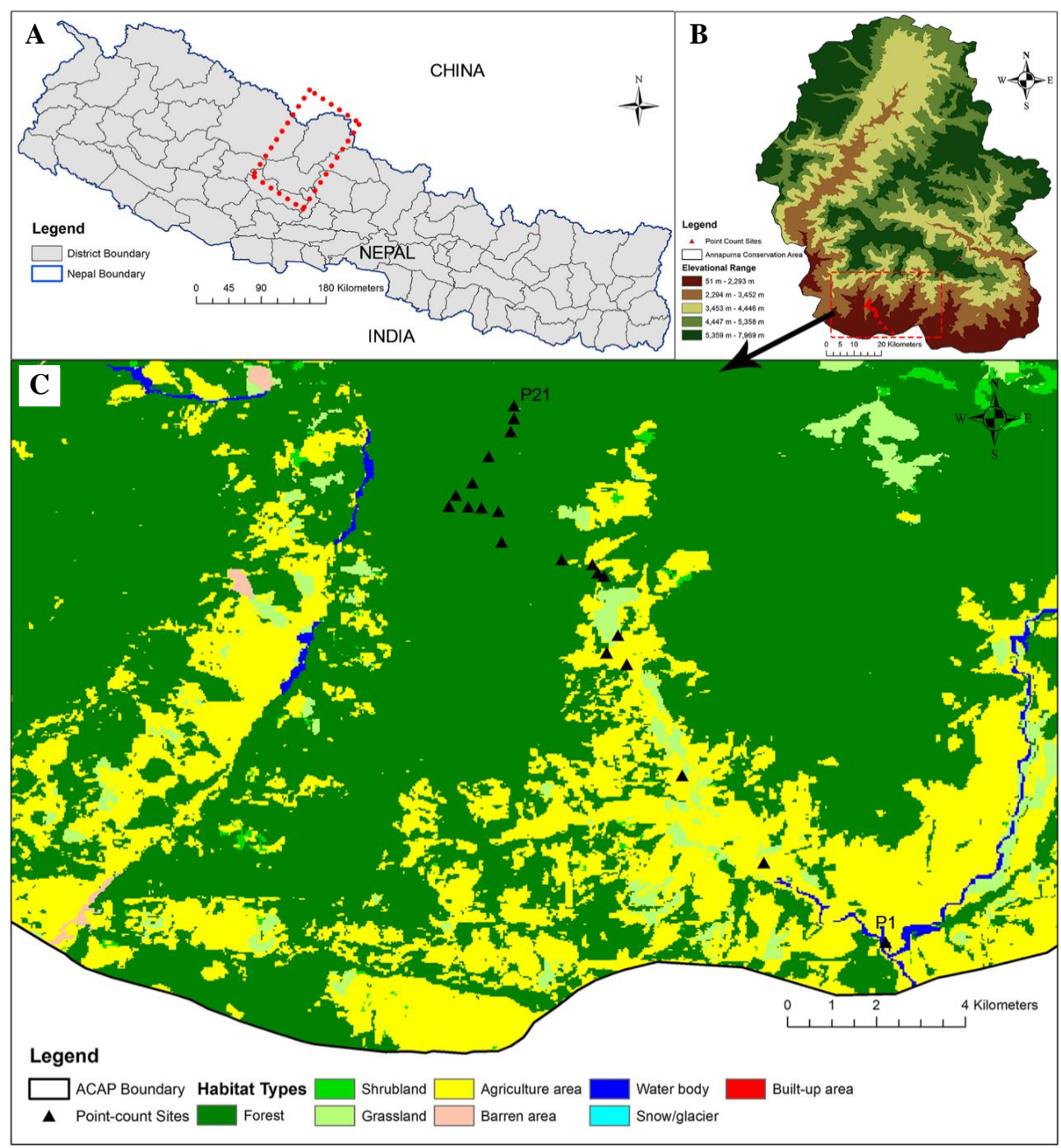

Figure 1. Map of the study area. A, Map of Nepal showing the Annapurna Conservation Area (ACA); B, Map of the ACA showing the elevational gradient; $\mathrm{C}$, Map of south-western region of the ACA showing the point-count stations (P1-P21) and habitat types 


\section{Bird survey}

Two seasonal field surveys were conducted in the winter (January-February) and the summer (May-June) of 2019. Point count method (Bibby et al. 2000) was used to survey bird abundance and diversity. Point count sites $(\mathrm{n}=$ 21) were set up with about every $100 \mathrm{~m}$ rise in elevation (Table 1), which was recorded by Garmin Etrex 10 GPS. Birds observed and heard within $50 \mathrm{~m}$ radius were recorded from a fixed point. Two censuses were conducted per season on each point. Time period for point count varied with habitat; for open space, it was 10 minutes and for dense forest, it was 20 minutes to detect rare and inconspicuous species (Aleixo and Galetti 1997; Dos Anjos and Boçon 1999). Bushnell Falcon 10×50 wide-angle binoculars were used and photographs were taken using Nikon p900 camera. Birds were observed from 30 minutes after dawn to 11:30 AM, and again from 3:00 PM till 30 minutes before sunset as practiced by (He et al. 2019). The field book 'Birds of Nepal' (Grimmett et al. 2016) was used for identification of birds.

\section{Data analysis}

Observed birds were classified into four feeding guildscarnivorous, frugivorous, omnivorous, and insectivorous, based on the diet descriptions available in Grimmett et al. (2016). Then, birds were classified based on habitat types (i.e. forest, pastureland, water-dependent land and agricultural land and settlement). All types of forest were included in forest type habitat; meadows, grassland and shrubby habitat with trees were included in pastureland; riverbank and marshy land were included in waterdependent land; farmlands and adjacent settlements were included in agricultural and settlement habitat. Distance from the nearest water source referred to numerical description of how far the water bodies were from the point count site. In this study, the distance to the nearest water source was measured with references to the Mardi River, Modi River, and Pau Khola. To test whether the sampling effort was enough to detect all the species that occur in the study area, species accumulation curve was produced, by plotting the cumulative number of species detected against the sampling effort (Willott 2001). To display relative species abundance of birds, the Rank Abundance Curve (RAC) or Whittaker plot was constructed using the abundance rank on the $\mathrm{x}$-axis and the relative abundance/proportion on the y-axis. The RAC can be effective in analyzing types of abundance distributions in communities and its shape is linked with ecological processes underpinning communities (Fisher et al. 1943; Izsák and Pavoine 2012). The relationships between bird species and different habitat types were analyzed using the ordination method- Canonical Correspondence Analysis (CCA). Species data on different feeding guilds were considered as response variable and habitat type data where those birds were recorded was predictor variable. All ordination plots were drawn using Canoco v.5.01 (Ter Braak \& Smilauer 1998).

\section{RESULTS AND DISCUSSION}

\section{Avian community structure}

A total of 673 bird individuals belonging to 13 orders, 35 families, and 112 species were recorded (Table S1).

Table 1. The 21 point count stations along the Mardi Himal Trekking route with GPS details and habitat features

\begin{tabular}{ccccl}
\hline Point count station & Longitude & Latitude & Elevation (m asl) & \multicolumn{1}{c}{ Habitat type } \\
\hline P1 & 83.9316 & 28.296 & 1030 & Riverbank \\
P2 & 83.8905 & 28.3295 & 1108 & Riverbank \\
P3 & 83.8793 & 28.3518 & 1193 & Agricultural land and Settlement \\
P4 & 83.8752 & 28.3541 & 1310 & Forest (Sub-tropical) \\
P5 & 83.8775 & 28.3576 & 1410 & Forest (Sub-tropical) \\
P6 & 83.8755 & 28.3008 & 1551 & Agricultural land and Settlement \\
P7 & 83.8747 & 28.3695 & 1648 & Forest (Upper Sub-tropical) \\
P8 & 83.8734 & 28.37009 & 1756 & Forest (Upper Sub-tropical) \\
P9 & 83.8723 & 28.3718 & 1862 & Agricultural land and Settlement \\
P10 & 83.8661 & 28.3728 & 1950 & Pastureland \\
P11 & 83.854 & 28.3763 & 2084 & Pastureland \\
P12 & 83.8533 & 28.3825 & 2175 & Pastureland \\
P13 & 83.8499 & 28.3832 & 2263 & Forest (Lower temperate) \\
P14 & 83.8472 & 28.3834 & 2342 & Pastureland \\
P15 & 83.8433 & 28.3835 & 2449 & Pastureland \\
P16 & 83.8447 & 28.3857 & 2515 & Forest (Temperate) \\
P17 & 83.8481 & 28.3882 & 2615 & Forest (Temperate) \\
P18 & 83.8514 & 28.3935 & 2735 & Forest (Upper Temperate) \\
P19 & 83.8558 & 28.3985 & 2825 & Forest (Upper Temperate) \\
P20 & 83.8565 & 28.4011 & 2945 & Pastureland (Sub-alpine grassland) \\
P11 & 83.8565 & 28.4037 & 3020 & Pastureland (Sub-alpine grassland) \\
\hline
\end{tabular}


Three globally threatened birds like Egyptian Vulture (Neophron percnopterus), Himalayan Vulture (Gyps himalayensis), River Lapwing (Vanellus duvaucelli) and the endemic bird of Nepal-Spiny Babbler (Turdoides nipalensis) were recorded. Birds from insectivorous (richness $=58$, abundance $=250$ ) feeding guild dominate the avian community, followed by frugivorous (richness $=$ 26 , abundance $=262$ ), omnivorous (richness $=14$, abundance $=116$ ) and carnivorous (richness $=14$, abundance $=45$ ). Similar dominance of insectivores has been reported from the eastern Himalaya (Chettri et al. 2018) and eastern part of the Nepal Himalaya (Kandel et al. 2018).

Out of 13 orders, order Passeriformes had the highest (77) number of species recorded and lowest (1) from orders- Bucerotiformes, Psittaciformes, Strigiformes and Anseriformes. Among the avian families, the highest number of species were recorded from family Muscicapidae (16), followed by family Leiotrichidae (8), and the least (1) were recorded from families- Anatidae, Cisticolidae, Psittacidae, Strigidae, Sturnidae, Upupidae, and Zosteropidae. Previous surveys and researches from the ACA found that avian community is dominated by order Passeriformes (Inskipp and Inskipp 2003; Neupane et al. 2020). Similar result was shown by other bird researches (Abbas et al. 2019; Abie et al. 2019; Adhikari et al. 2019; Chaudhari et al. 2009). The species accumulation curve based on observed species richness of both seasons is almost linear indicating the likelihood of encountering more species with increasing sampling effort. An almost similar type of pattern was observed for both the summer and winter seasons (Figure 2). The last point count site changes to high elevational meadows in the summer season and is covered by snow for more than nine months. Such type of seasonal habitat and presence of bird refugia in mountain might be the reason for linear nature of accumulation curve. Glacial mountains and high elevation topography have refugia for birds and animals from other taxa too (Wu et al. 2017; Abbas et al. 2019).

\section{Avian richness and abundance}

Species richness curve based on observed species richness showed that the richness initially was lesser, then gradually increased at mid-elevation and declined with further increase in elevation forming a hump-shaped pattern. Almost similar type of pattern was observed for both summer and winter season (Figure 3). However, the curves were not smoothly unimodal, indicating that elevation is not the sole driver of the avian richness. The lower richness in initial points might be due to high anthropogenic disturbances like roads and construction of hydropower stations. Though few generalist species might be benefitted (Marcum 2006) but, in general, anthropogenic disturbances have significant negative effects to bird richness and abundance (Canaday 1996; Gove et al. 2008; Marcum 2006). Omnivorous species have less effect of disturbances than other feeding guilds. Peak of the bird richness and abundance at mid-elevation might also be due to edge effect of agricultural fields and forest. Both farm and forest birds were recorded at this elevation. Edge effect has been observed in avian communities such that edge creates attractive habitats and have higher bird diversities due to heterogeneity of edge vegetation (Deikumah et al. 2017; Flaspohler et al. 2001). Not only that, forest edge has shrubby habitat which favors more richness and abundance (Wuczyński 2016).

The rank abundance curve (RAC) showed a steep gradient (Figure 4) indicating low evenness as the highranking species have much higher abundances than the low-ranking species. We observed a lognormal theoretical species abundance distribution that a convex segment of the RAC close to the y-axis is followed by a concave segment. This type of RAC is common mostly in cases of equilibrium communities subjected to many controlling factors ((Izsák 2008).

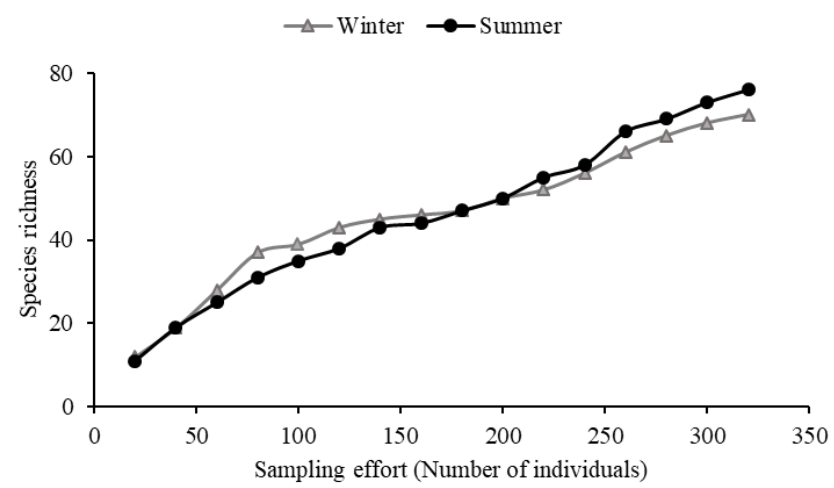

Figure 2. Species accumulation curve of birds recorded in the Mardi Himal, Nepal
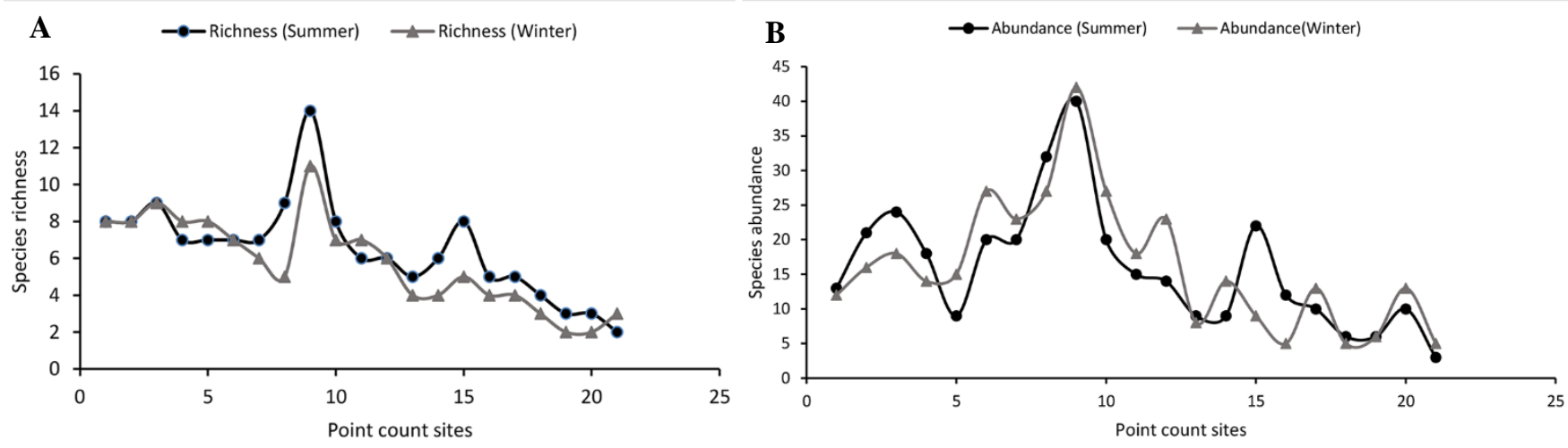

Figure 3. Seasonal species richness curve and seasonal species abundance curve of birds recorded in the Mardi Himal, Nepal 


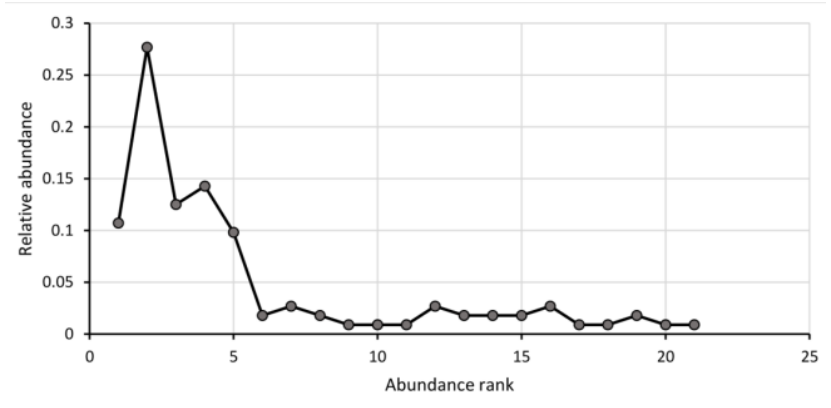

Figure 4. Rank abundance curve of bird species recorded in the Mardi Himal, Nepal

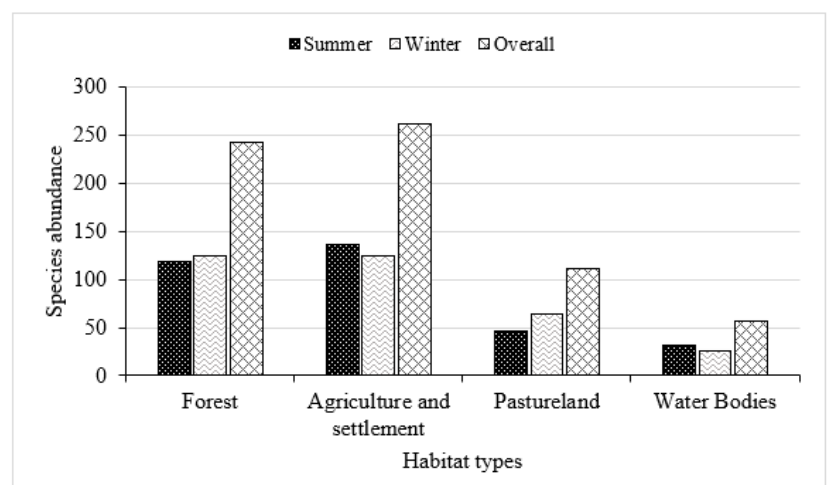

Figure 5. Habitat-wise bird species abundance for the two seasons recorded in Mardi Himal, Nepal.

\section{Season wise habitat association of avian community}

The overall species abundance was the highest in agricultural land and settlement followed by forest and was found lowest in water-dependent habitat. Species abundance varies with season in different habitat types. In summer, abundance of agriculture/settlement and waterdependent habitat was found higher. Likewise, in winter, abundance of forest and pastureland reliant species was found higher (Figure 5).

Season wise habitat association was tested for selected habitat types- forest habitat, pastureland, wetlanddependent habitat, and agricultural land and settlement. The Monte-Carlo permutation test of significance of all canonical axes revealed significant preference of the insectivorous species in summer $($ Trace $=2.181$, F-ratio $=$ 1.289, $\mathrm{P}=0.04$ ) to different habitat types (Figure 6). Similarly, omnivorous birds also showed significant association with habitat types in both summer and winter season (summer: Trace $=1.524, \mathrm{~F}$-ratio $=1.566, \mathrm{P}=0.047$ and winter: Trace $=1.480$, F-ratio $=2.169, \mathrm{P}=0.002$ ). However, the Monte-Carlo permutation test of significance of all canonical axes showed no significant relationship of the insectivorous in winter (Trace $=1.928$, F-ratio $=1.099$, $\mathrm{P}=0.202$ ), carnivorous in both seasons (summer: Trace $=$ 1.632, F-ratio $=1.277, \mathrm{P}=0.156$ and winter Trace $=2.042$, F-ratio $=0.742, P=0.776)$ and frugivorous species in both seasons (summer: Trace $=1.577, \mathrm{~F}$-ratio $=1.241, \mathrm{P}=0.14$ and winter Trace $=1.516$, F-ratio $=0.970, \mathrm{P}=0.536$ ) to the habitat types (Figure 7).

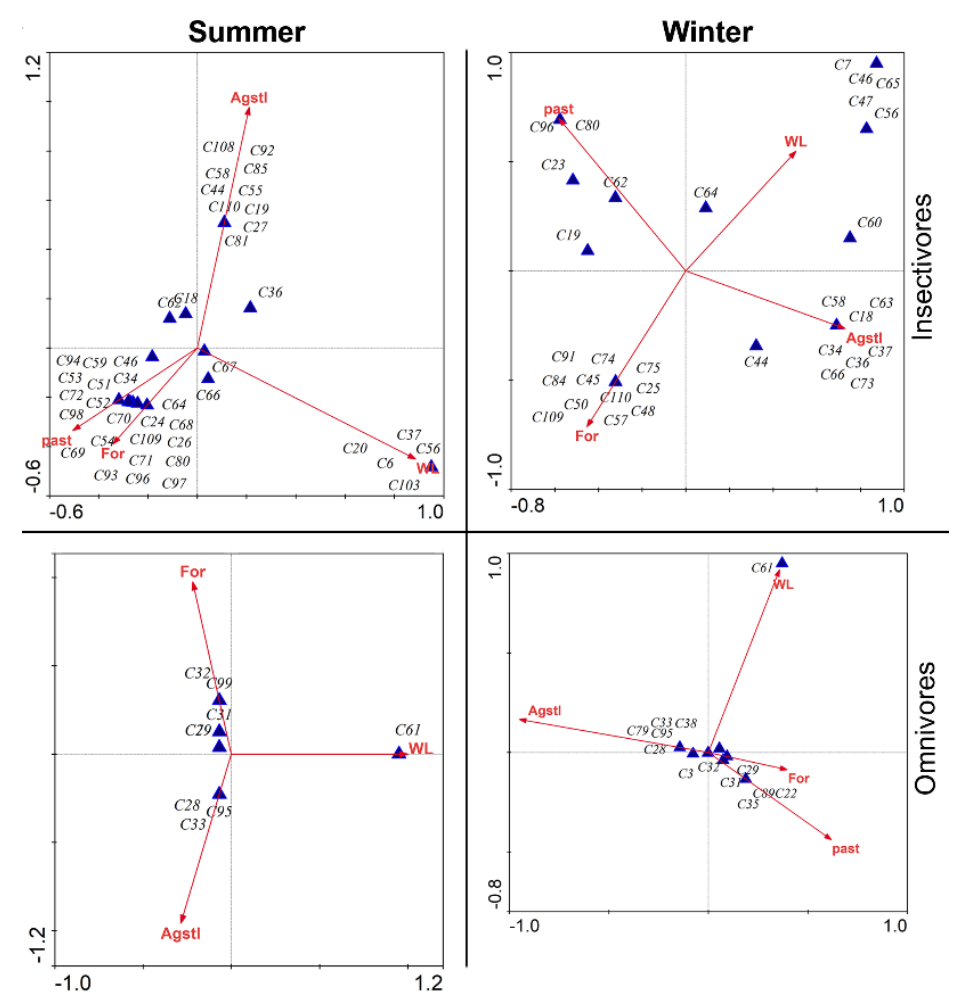

Figure 6. CCA ordination diagram (biplot) showing response of insectivores and omnivores to habitat variables in two seasons. Abbreviations: Past: pastureland, WL: Wetland dependent habitat, Agstl: Agricultural land and settlement, and For: Forest. Codes used for bird species are included in Table $\mathrm{S} 1$ 


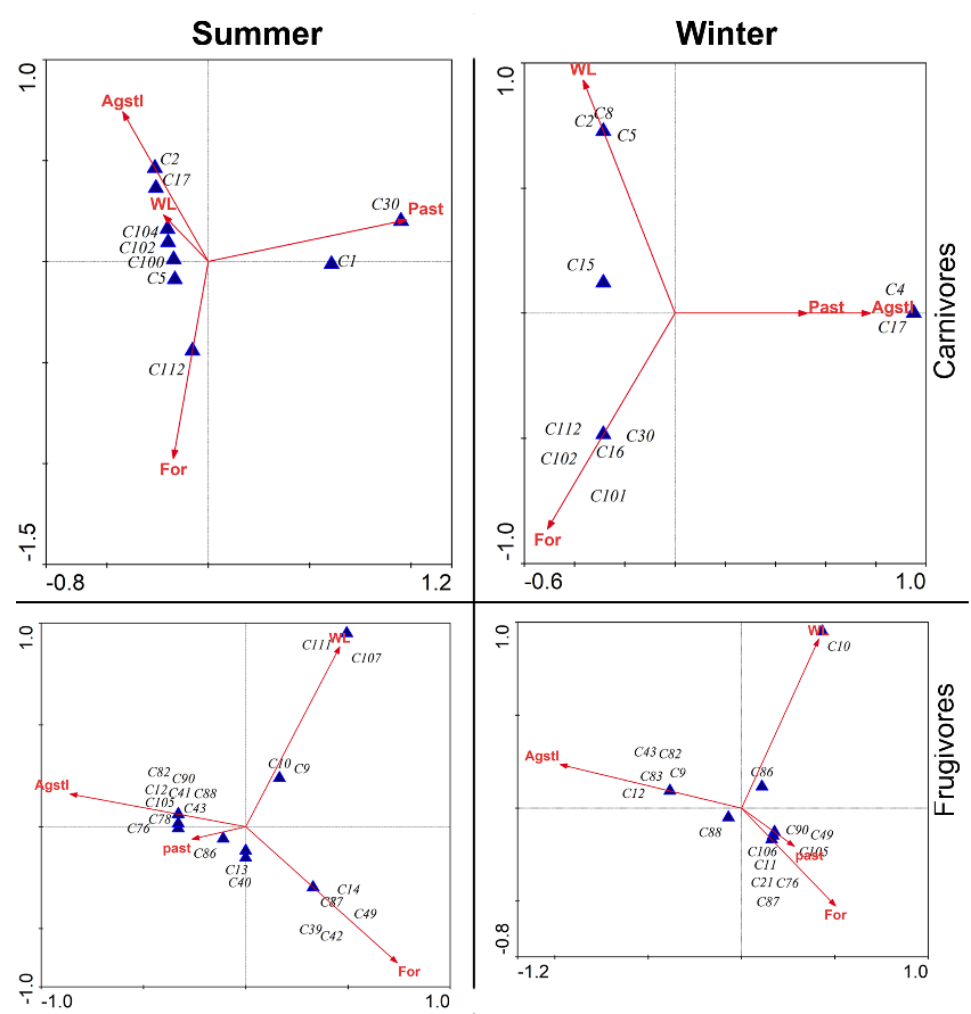

Figure 7. CCA ordination diagram (biplot) showing response of carnivores and frugivores to habitat variables in two seasons. Abbreviations: Past: pastureland, WL: Wetland dependent habitat, Agstl: Agricultural land and settlement, and For: Forest. Codes used for bird species are included in Table $\mathrm{S} 1$

Certain types of birds are confined to specific habitats such as agricultural fields, shrubs or forests, etc. These ranges of habitat provide different kinds of food, easy availability of water and mates for nesting or reproduction (Baschuk et al. 2012; Fernández Cañero and González Redondo 2010) thus are distributed heterogeneously. We observed a negative correlation of species richness with distance to the nearest water source (GLM; summer, $r=$ $0.004, p=0.014$; winter, $r=-0.003, P=0.109$ ) which means bird richness decreases with an increase in distance to water sources. $\mathrm{Li}$ et al. (2013) concluded that avian species richness is a hump-shaped function of energy availability, but a linear function of water availability and further emphasized that water availability has strong effects on plant richness and weaker effects on vertebrate richness. Likewise, Currie (1991) observed that the richness of vertebrates (birds, mammals, amphibians, and reptiles) is more influenced by energy while the same in the tree species are more influenced by water availability. The influence of water on plants presumably affects vertebrate species richness staunchly since plants are the chief source of food and habitat and fulfill their dietary requirements and niche (Kissling et al. 2007).

We observed no specific association of the frugivorous and carnivorous birds with the habitat types or the resource availability. Frugivorous are relatively flexible to switch to other resources in response to fluctuations in fruit resource availability (Bender et al. 2017), and hence are less specific to the habitats and more specific to fruiting season.
Ordination analysis revealed a significant relationship of insectivorous and omnivorous birds to specific habitats. Herzog et al. (2005) conducted avian research in Swiss agricultural landscape and found that pastureland didn't contribute to bird diversity. Contrarily, this study showed that pasture grasslands support many insectivorous bird species, which is consistent with the results from previous studies (Söderström et al. 2001; Tanis et al. 2020; Zahn et al. 2010). Higher food availability in grasslands may be the reason for supporting bird diversity (Jokimäki et al. 1996; Nilsson 1979). Likewise, in our study, we found that omnivorous species are mostly found in forest habitats. Similar results were shown by studies around the globe (Dario 2017; Mahiga et al. 2019). Insectivorous birds are the habitat specialists and are least dispersive or residential (He et al. 2019), hence are more specialized to the habitat. Habitat conditions such as landscape-level habitat heterogeneity are important determinants of the distribution of avian species (Basnet et al. 2016). Therefore, the presence of multiple habitat types is also a driver of the avian species assemblage in Mardi Himal.

This study from Mardi Himal of central Nepal found that Muscicapidae family and order Passeriformes were dominant in avian community. Species richness curve peaked at mid-elevation and species accumulation curve was linear. The highest species abundance was recorded in agricultural land and settlement. Frugivorous and carnivorous birds did not show significant relationship to the habitat types whereas insectivorous and omnivorous 
bird species showed their significant association to pastureland and forest habitats, respectively. An extensive avian survey covering all seasons is important for further exploration, which might play a crucial role in developing baseline information and implementing conservation actions in the central Himalaya.

\section{ACKNOWLEDGEMENTS}

We would like to thank Department of National Parks and Wildlife Conservation, Government of Nepal, and Annapurna Conservation Area Project, Pokhara for granting research permission. We thank Shiva Prasad Bhandari of Mardi Himal Eco-Village for providing accommodation during field. NP, LK, and MKC conceptualized the study. NP, NC and KDS performed field survey and gathered data. NP, LK and BPB analyzed data. NP and LK prepared the manuscript. MKC supervised the research. All authors read the manuscript, contributed to its improvement, and approved for submission.

\section{REFERENCES}

Abbas S, Hussain E, Abbas H, Hussain S, Tabassum R, Khan MZ, Nabi M. 2019. Species diversity, feeding habits and conservation status of birds in Qurumbar National Park, Gilgit-Baltistan, Pakistan. Intl J Zool Invest 5 (2): 108-117. DOI: 10.33745/ijzi.2019.v05i02.009

Abie K, Tilahun B, Feyisa A, Kumssa T, Alemneh A. 2019. Bird species diversity and distribution in case of protected area. Species 20: 90 100.

Adhikari JN, Bhattarai BP, Thapa TB. 2019. Factors affecting diversity and distribution of threatened birds in Chitwan National Park, Nepal. J. Threat. Taxa 11 (5): 13511-13522. DOI: 10.11609/jott.4137.11.5.13511-13522

Aleixo A, Galetti M. 1997. The conservation of the avifauna in a lowland Atlantic forest in south-east Brazil. Bird Conservation International 7 (3): 235-261. DOI: 10.1017/S0959270900001556

Amani M, Salehi B, Mahdavi S, Brisco B. 2018. Spectral analysis of wetlands using multi-source optical satellite imagery. ISPRS J. Photogramm. Remote Sens 144: 119-136. DOI: 10.1016/j.isprsjprs.2018.07.005

Baschuk MS, Koper N, Wrubleski DA, Goldsborough G. 2012. Effects of water depth, cover and food resources on habitat use of marsh birds and waterfowl in boreal wetlands of Manitoba, Canada. Waterbirds 35 (1): 44-55. DOI: 10.1675/063.035.0105.

Basnet TB, Rokaya MB, Bhattarai BP, Münzbergová Z. 2016 Heterogeneous landscapes on steep slopes at low altitudes as hotspots of bird diversity in a Hilly Region of Nepal in the Central Himalayas. PloS ONE 11 (3): e0150498. DOI: 10.1371/journal.pone.0150498

BCN. 2011. The state of Nepal's birds 2010. Bird Conservation of Nepal and Department of National Parks and Wildlife Conservation. Kathmandu, Nepal.

Bender IM, Kissling WD, Böhning-Gaese K, Hensen I, Kühn I, Wiegand T, Schleuning M. 2017. Functionally specialised birds respond flexibly to seasonal changes in fruit availability. J Anim Ecol 86 (4) 800-811. DOI: 10.1111/1365-2656.12683.

Beuel S, Alvarez M, Amler E, Behn K, Kotze D, Kreye C, Ziegler S. 2016. A rapid assessment of anthropogenic disturbances in East African wetlands. Ecol Indic 67: 684-692. DOI: 10.1016/j.ecolind.2016.03.034

Bibby CJ, Burgess ND, Hill DA, Mustoe S. 2000. Bird Census Techniques. Elsevier, Nederland.

Blake JG, Loiselle BA. 2000. Diversity of birds along an elevational gradient in the Cordillera Central, Costa Rica. The Auk 117: 663-686.

Brawn JD, Robinson SK, Thompson III FR. 2001. The role of disturbance in the ecology and conservation of birds. Annu Rev Ecol Evol Syst 32 (1): 251-276. DOI: 10.1146/annurev.ecolsys.32.081501.114031.
Canaday C. 1996. Loss of insectivorous birds along a gradient of human impact in Amazonia. Biol Conserv 77 (1): 63-77. DOI: 10.1016/00063207(95)00115-8.

Chaudhari UK, Kafle G, Baral HS. 2009. Avifaunal diversity of Khata Corridor Forest. J Wetlands Ecol 2 (1): 48-56. DOI: 10.3126/jowe.v2i1.1857.

Chettri A, Sharma K, Dewan S, Acharya BK. 2018. Bird diversity of tea plantations in Darjeeling Hills, Eastern Himalaya, India. Biodiversitas 19 (3): 1066-1073. DOI:10.13057/biodiv/d190339.

Chettri N, Sharma E, Deb D. 2001. Bird community structure along a trekking corridor of Sikkim Himalaya: a conservation perspective. Biol Conserv 102 (1): 1-16. DOI: 10.1016/S0006-3207(01)00092-1.

Cresswell WR, Wilson JM, Vickery J, Jones P, Holt S. 2007. Changes in densities of Sahelian bird species in response to recent habitat $\begin{array}{llll}\text { degradation. Ostrich } 78 & \text { (2): 247-253. DOI: }\end{array}$ 10.2989/OSTRICH.2007.78.2.20.100.

Currie DJ. 1991. Energy and large-scale patterns of animal-and plantspecies richness. Am Nat 137 (1): 27-49.

Dario FR. 2017. Diversity of frugivorous and omnivorous birds in different stages of ecological succession in Amazon Rainforest fragments. World News Nat Sci 15: 37-48.

Deikumah JP, Kwafo R, Konadu VA. 2017. Land use types influenced avian assemblage structure in a forest-agriculture landscape in Ghana. Ecol Evol 7 (21): 8685-8697. DOI: 10.1002/ece3.3355

Dos Anjos L, Boçon R. 1999. Bird communities in natural forest patches in southern Brazil. Wilson Bull 11 (3): 397-414.

Fernández Cañero R, González Redondo P. 2010. Green roofs as a habitat for birds: a review. J Anim Vet Adv 9 (15): 2041-2052. DOI: 10.3923/javaa.2010.2041.2052.

Fisher RA, Corbet AS, Williams CB. 1943. The relation between the number of species and the number of individuals in a random sample of an animal population. J Anim Ecol 12: 42-58.

Flaspohler DJ, Temple SA, Rosenfield RN. 2001. Species-specific edge effects on nest success and breeding bird density in a forested landscape. Ecol Appl 11(1): 32-46.

Girma Z, Mamo Y, Mengesha G, Verma A, Asfaw T. 2017. Seasonal abundance and habitat use of bird species in and around Wondo Genet Forest, south-central Ethiopia. Ecol Evol 7 (10): 3397-3405. DOI: $10.1002 /$ ece 3.2926 .

Gove AD, Hylander K, Nemomisa S, Shimelis A. 2008. Ethiopian coffee cultivation-Implications for bird conservation and environmental certification. Conserv Lett 1 (5): 208-216.

Grimmett R, Inskipp C, Inskipp T, Baral HS. (2016). Birds of Nepal: Bloomsbury Publishing. New York, USA

He X, Wang X, DuBay S, Reeve AH, Alström P, Ran J, Wu Y. 2019. Elevational patterns of bird species richness on the eastern slope of Mt. Gongga, Sichuan Province, China. Avian Res 10 (1). DOI: 10.1186/s40657-018-0140-7

Herzog F, Dreier S, Hofer G, Marfurt C, Schüpbach B, Spiess M, Walter T. 2005. Effect of ecological compensation areas on floristic and breeding bird diversity in Swiss agricultural landscapes. Agric Ecosyst Environ 108 (3): 189-204

Inskipp C, Inskipp T. 2003. Bird conservation priorities of the Annapurna Conservation Area. Report submitted to UNEP-WCMC/King Mahendra Trust for Nature Conservation/Annapurna Conservation Area Project, Thailand.

Izsák J, Pavoine, S. 2012. Links between the species abundance distribution and the shape of the corresponding rank abundance curve. Ecol Indic 14 (1): 1-6. DOI: 10.1016/j.ecolind.2011.06.030.

Izsák R. 2008. Maximum likelihood fitting of the Poisson lognormal distribution. Environ Ecol Stat 15: 143-156.

Jokimäki J, Suhonen J, Inki K, Jokinen S. 1996. Biogeographical comparison of winter bird assemblages in urban environments in Finland. J Biogeogr 23 (3): 379-386.

Kandel P, Thapa I, Chettri N, Pradhan R, Sharma E. 2018. Birds of the Kangchenjunga Landscape, the Eastern Himalaya: status, threats and implications for conservation. Avian Res 9 (1). DOI: 10.1186/s40657018-0100-2.

Kawamura K, Yamaura Y, Senzaki M, Ueta M, Nakamura F. 2019. Seasonality in spatial distribution: Climate and land use have contrasting effects on the species richness of breeding and wintering birds. Ecol Evol 9 (13): 7549-7561. DOI: 10.5061/dryad.7n404q0.

Kissling WD, Rahbek C, Böhning-Gaese K. 2007. Food plant diversity as broad-scale determinant of avian frugivore richness. Proc Biol Sci 274 (1611): 799-808. DOI: 10.1098/rspb.2006.0311 
Li L, Wang Z, Zerbe S, Abdusalih N, Tang Z, Ma M, Fang J. 2013 Species richness patterns and water-energy dynamics in the drylands of Northwest China. PLoS ONE 8 (6): e66450. DOI: 10.1371/journal.pone.0066450

Mahiga SN, Webala P, Mware MJ, Ndang'Ang'A PK. 2019. Influence of Land-Use Type on Forest Bird Community Composition in Mount Kenya Forest. Int J Ecol 8248270. DOI: 10.1155/2019/8248270

Marcum HA. 2006. The effects of human disturbance on birds in Bastrop State Park. A\&M University, Texas USA.

McCain CM. 2009. Global analysis of bird elevational diversity. Glob Ecol Biogeogr 18 (3): 346-360. DOI: 10.1111/j.14668238.2008.00443.x

Neupane J, Khanal L, Chalise MK. 2020. Avian diversity in Kaligandaki River basin, Annapurna Conservation Area, Nepal. International Journal of Ecology and Environmental Sciences 46(2): 99-110.

Nilsson SG. 1979. Density and species richness of some forest bird communities in South Sweden. Oikos 33 (3): 392-401.

Norvell RE, Howe FP, Parrish JR. 2003. A seven-year comparison of relative-abundance and distance-sampling methods. The Auk 120 (4): 1013-1028. DOI: 10.1093/auk/120.4.1013

Pandey N, Khanal L, Chalise MK. 2020. Correlates of avifaunal diversity along the elevational gradient of Mardi Himal in Annapurna Conservation Area, Central Nepal. Avian Res 11 (1): 31. DOI:10.1186/s40657-020-00217-6

Sauer JR, Link WA. 2002. Hierarchical modeling of population stability and species group attributes from survey data. Ecology 83 (6): 1743 1751. DOI: 10.1890/0012-9658(2002)083[1743:HMOPSA]2.0.CO;2

Seoane J, Villen-Perez S, Carrascal LM. 2013. Environmental determinants of seasonal changes in bird diversity of Mediterranean oakwoods. Ecol Res 28 (3): 435-445. DOI: 10.1007/s11284-013$1032-2$

Seymour C, Simmons R. 2008. Can severely fragmented patches of riparian vegetation still be important for arid-land bird diversity? J Arid Environ 72 (12): 2275-2281. DOI: 10.1016/j.jaridenv.2008.07.014
Shiu HJ, Lee PF. 2003. Seasonal variation in bird species richness along elevational gradients in Taiwan. Acta Zoologica Taiwanica 14: 1-21.

Shoo LP, Williams SE, Hero JM. 2005. Climate warming and the rainforest birds of the Australian Wet Tropics: Using abundance data as a sensitive predictor of change in total population size. Biol Conserv 125: 335-343.

Söderström B, Pärt T, Linnarsson E. 2001. Grazing effects on between-year variation of farmland bird communities. Ecol Appl 11 (4): $\quad 1141-1150$. $\quad$ DOI: $10.1890 / 1051-$ 0761(2001)011[1141:GEOBYV]2.0.CO;2.

Tanis MM, Marshall L, Biesmeijer JK, van Kolfschoten L. 2020. Grassland management for meadow birds in the Netherlands is unfavourable to pollinators. Basic Appl Ecol 43: 52-63. DOI: 10.1016/j.baae.2019.12.002

Ter Braak CJF, Smilauer P. 1998. CANOCO reference manual and user's guide to Canoco for Windows: software for canonical community ordination (version 4). Microcomputer Power, Ithaca, NY.

Vallecillo S, Maes J, Polce C, Lavalle C. 2016. A habitat quality indicator for common birds in Europe based on species distribution models. Ecol Indic 69: 488-499. DOI: 10.1016/j.ecolind.2016.05.008.

Veraart J, De Groot R, Perelló G, Riddiford N, Roijackers R. 2004. Selection of (bio) indicators to assess effects of freshwater use in wetlands: a case study of s' Albufera de Mallorca, Spain. Reg Environ Change 4 (2-3): 107-117. DOI: 10.1007/s10113-004-0070-2.

Willott, S. 2001. Species accumulation curves and the measure of sampling effort. J Appl Ecol 38:484-486.

Wu Y, DuBay SG, Colwell RK, Ran J, Lei F. 2017. Mobile hotspots and refugia of avian diversity in the mountains of south-west China under past and contemporary global climate change. J Biogeogr 44 (3): 615626. DOI: $10.1111 / \mathrm{jbi} .12862$.

Wuczyński A. 2016. Farmland bird diversity in contrasting agricultural landscapes of southwestern Poland. Landsc Urban Plan 148: 108-119. DOI: 10.1016/j.landurbplan.2015.11.010.

Zahn A, Englmaier I, Drobny M. 2010. Food availability for insectivores in grasslands- arthropod abundance in pastures, meadows and fallow land. Appl Ecol Environ Sci 8 (2): 87-100. 
Table S1. List of birds recorded in Mardi Himal, Nepal with taxonomic positions, feeding guilds and codes used for ordination analysis

\begin{tabular}{|c|c|c|c|c|c|}
\hline Bird & Scientific Name & Order & Family & Feeding Guild & Bird Code \\
\hline Himalayan Vulture & Gyps himalayensis & Accipitriformes & Accipitrinae & Carnivorous & $\mathrm{C} 1$ \\
\hline Egyptian Vulture & Neophron percnopterus & Accipitriformes & Accipitridae & Carnivorous & $\mathrm{C} 2$ \\
\hline Black Kite & Milvus migrans & Accipitriformes & Accipitridae & Omnivorous & $\mathrm{C} 3$ \\
\hline Himalayan Buzzard & Buteo buteo & Accipitriformes & Accipitridae & Carnivorous & $\mathrm{C} 4$ \\
\hline Goosander & Mergus merganser & Anseriformes & Anatidae & Carnivorous & $\mathrm{C} 5$ \\
\hline Hoopoe & Uрира ерорs & Bucerotiformes & Upupidae & Insectivorous & C6 \\
\hline Red-wattled Lapwing & Vanellus indicus & Charadriiformes & Charadriidae & Insectivorous & $\mathrm{C} 7$ \\
\hline River Lapwing & Vanellus duvaucelii & Charadriiformes & Charadriidae & Carnivorous & $\mathrm{C} 8$ \\
\hline Oriental Turtle Dove & Streptopelia orientalis & Columbiformes & Columbidae & Frugivorous & C9 \\
\hline Spotted Dove & Stigmatopelia chinensis & Columbiformes & Columbidae & Frugivorous & $\mathrm{C} 10$ \\
\hline Speckled Wood Pigeon & Columba hodgsonii & Columbiformes & Columbidae & Frugivorous & $\mathrm{C} 11$ \\
\hline Common Pigeon & Columba livia & Columbiformes & Columbidae & Frugivorous & $\mathrm{C} 12$ \\
\hline Barred Cuckoo Dove & Macropygia unchall & Columbiformes & Columbidae & Frugivorous & $\mathrm{C} 13$ \\
\hline Wedge-tailed Green Pigeon & Treron sphenurus & Columbiformes & Columbidae & Frugivorous & $\mathrm{C} 14$ \\
\hline Common Kingfisher & Alcedo atthis & Coraciiformes & Alcedinidae & Carnivorous & $\mathrm{C} 15$ \\
\hline Blue-eared Kingfisher & Alcedo meninting & Coraciiformes & Alcedinidae & Carnivorous & $\mathrm{C} 16$ \\
\hline White-throated Kingfisher & Halcyon smyrnensis & Coraciiformes & Alcendinidae & Carnivorous & $\mathrm{C} 17$ \\
\hline Lesser Coucal & Centropus bengalensis & Cuculiformes & Cuculidae & Insectivorous & $\mathrm{C} 18$ \\
\hline Eurasian Cuckoo & Cuculus canorus & Cuculiformes & Cuculidae & Insectivorous & $\mathrm{C} 19$ \\
\hline Indian Cuckoo & Cuculus micropterus & Cuculiformes & Cuculidae & Insectivorous & $\mathrm{C} 20$ \\
\hline Black Francolin & Francolinus francolinus & Galliformes & Phasianidae & Frugivorous & $\mathrm{C} 21$ \\
\hline Kalij Pheasant & Lophura leucomelanos & Galliformes & Phasianidae & Omnivorous & $\mathrm{C} 22$ \\
\hline Black-throated Tit & Aegithalos concinnus & Passeriformes & Aegithalidae & Insectivorous & $\mathrm{C} 23$ \\
\hline Rufous-fronted Tit & Aegithalos iouschistos & Passeriformes & Aegithalidae & Insectivorous & $\mathrm{C} 24$ \\
\hline Scarlet Minivet & Perricrocotus flammeus & Passeriformes & Campephagidae & Insectivorous & $\mathrm{C} 25$ \\
\hline Black-winged Cuckooshrike & Coracina melaschistos & Passeriformes & Campephagidae & Insectivorous & $\mathrm{C} 26$ \\
\hline Straited Prinia & Prinia crinigera & Passeriformes & Cisticolidae & Insectivorous & $\mathrm{C} 27$ \\
\hline House Crow & Corvus splendens & Passeriformes & Corvidae & Omnivorous & $\mathrm{C} 28$ \\
\hline Grey Treepie & Dendrocitta formosae & Passeriformes & Corvidae & Omnivorous & $\mathrm{C} 29$ \\
\hline Common Green Magpie & Cissa chinensis & Passeriformes & Corvidae & Carnivorous & $\mathrm{C} 30$ \\
\hline Large-billed Crow & Corvus macrorhynchos & Passeriformes & Corvidae & Omnivorous & $\mathrm{C} 31$ \\
\hline Yellow-billed Blue Magpie & Urocissa flavirostris & Passeriformes & Corvidae & Omnivorous & $\mathrm{C} 32$ \\
\hline Red-billed Blue Magpie & Urocissa erythrorhyncha & Passeriformes & Corvidae & Omnivorous & $\mathrm{C} 33$ \\
\hline Red-billed Chough & Pyrrhocorax pyrrhocorax & Passeriformes & Corvidae & Insectivorous & $\mathrm{C} 34$ \\
\hline Alpine Chough & Pyrrhocorax graculus & Passeriformes & Corvidae & Omnivorous & $\mathrm{C} 35$ \\
\hline Black Drongo & Dicrurus macrocercus & Passeriformes & Dicruridae & Insectivorous & $\mathrm{C} 36$ \\
\hline Ashy Drongo & Dicrurus leucophaeus & Passeriformes & Dicruridae & Insectivorous & $\mathrm{C} 37$ \\
\hline Rock Bunting & Emberiza cia & Passeriformes & Emberizidae & Omnivorous & $\mathrm{C} 38$ \\
\hline Crested Bunting & Melophus lathami & Passeriformes & Emberizidae & Frugivorous & C39 \\
\hline Dark-breasted Rosefinch & Carpodacus nipalensis & Passeriformes & Fringillidae & Frugivorous & $\mathrm{C} 40$ \\
\hline Spot-winged Rosefinch & Carpodacus rodopeplus & Passeriformes & Fringillidae & Frugivorous & $\mathrm{C} 41$ \\
\hline Spot-winged Grosbeak & Mycerobas melanozanthos & Passeriformes & Fringillidae & Frugivorous & $\mathrm{C} 42$ \\
\hline Common Rosefinch & Carpodacus erythrinus & Passeriformes & Fringillidae & Frugivorous & $\mathrm{C} 43$ \\
\hline Barn Swallow & Hirundo rustica & Passeriformes & Hirundinidae & Insectivorous & $\mathrm{C} 44$ \\
\hline Eurasian Crag Martin & Ptyonoprogne rupestris & Passeriformes & Hirundinidae & Insectivorous & $\mathrm{C} 45$ \\
\hline Long-tailed Shrike & Lanius schach & Passeriformes & Laniidae & Insectivorous & $\mathrm{C} 46$ \\
\hline Grey-backed Shrike & Lanius tephronotus & Passeriformes & Laniidae & Insectivorous & $\mathrm{C} 47$ \\
\hline White-crested Laughingthrush & Garrulax leucolophus & Passeriformes & Leiotrichidae & Insectivorous & $\mathrm{C} 48$ \\
\hline Rufous Sibia & Malacias capistratus & Passeriformes & Leiotrichidae & Frugivorous & $\mathrm{C} 49$ \\
\hline Variegated Laughingthrush & Garrulax variegatus & Passeriformes & Leiotrichidae & Insectivorous & $\mathrm{C} 50$ \\
\hline Striated Laughingthrush & Garrulax striatus & Passeriformes & Leiotrichidae & Insectivorous & $\mathrm{C} 51$ \\
\hline Streaked Laughingthrush & Garrulax squamatus & Passeriformes & Leiotrichidae & Insectivorous & $\mathrm{C} 52$ \\
\hline Hoary-throated Barwing & Actinodura nipalensis & Passeriformes & Leiotrichidae & Insectivorous & $\mathrm{C} 53$ \\
\hline White-throated Laughingthrush & Garrulax albogularis & Passeriformes & Leiotrichidae & Insectivorous & $\mathrm{C} 54$ \\
\hline Spiny Babbler & Turdoides nipalensis & Passeriformes & Leiotrichidae & Insectivorous & $\mathrm{C} 55$ \\
\hline White-browed Wagtail & Motacilla maderaspatensis & Passeriformes & Motacillidae & Insectivorous & $\mathrm{C} 56$ \\
\hline Upland pipit & Anthus Sylvanus & Passeriformes & Motacillidae & Insectivorous & C57 \\
\hline Paddyfield Pipit & Anthus rufulus & Passeriformes & Motacillidae & Insectivorous & $\mathrm{C} 58$ \\
\hline Grey Wagtail & Motacilla cinerea & Passeriformes & Motacillidae & Insectivorous & C59 \\
\hline Spotted Forktail & Enicurus maculatus & Passeriformes & Muscicapidae & Insectivorous & C60 \\
\hline Plumbeous Water Redstart & Rhyacornis fuliginosa & Passeriformes & Muscicapidae & Omnivorous & C61 \\
\hline Grey Bushchat & Saxicola ferreus & Passeriformes & Muscicapidae & Insectivorous & C62 \\
\hline Blue Whistling Thrush & Mypphonus caeruleus & Passeriformes & Muscicapidae & Insectivorous & $\mathrm{C} 63$ \\
\hline
\end{tabular}




\begin{tabular}{|c|c|c|c|c|c|}
\hline Pied Bushchat & Saxicola caprata & Passeriformes & Muscicapidae & Insectivorous & C64 \\
\hline White-capped Redstart & Chaimarronis leucocephalus & Passeriformes & Muscicapidae & Insectivorous & C65 \\
\hline Verditer Flycatcher & Eumyias thalassinus & Passeriformes & Muscicapidae & Insectivorous & C66 \\
\hline Rufous-bellied Niltava & Niltava sundara & Passeriformes & Muscicapidae & Insectivorous & C67 \\
\hline Blue-capped Rock Thrush & Monticola cinclorhynchus & Passeriformes & Muscicapidae & Insectivorous & C68 \\
\hline Little Pied Flycatcher & Ficedula westermanni & Passeriformes & Muscicapidae & Insectivorous & C69 \\
\hline White-browed Bush Robin & Tarsiger indicus & Passeriformes & Muscicapidae & Insectivorous & $\mathrm{C} 70$ \\
\hline Pale Blue Flycatcher & Cyornis unicolor & Passeriformes & Muscicapidae & Insectivorous & C71 \\
\hline Indian Blue Robin & Luscinia brunnea & Passeriformes & Muscicapidae & Insectivorous & $\mathrm{C} 72$ \\
\hline Common Stonechat & Saxicola leucurus & Passeriformes & Muscicapidae & Insectivorous & $\mathrm{C} 73$ \\
\hline Hodgson's Redstart & Phoenicurus hodgsoni & Passeriformes & Muscicapidae & Insectivorous & $\mathrm{C} 74$ \\
\hline Himalayan Bluetail & Tarsiger rufilatus & Passeriformes & Muscicapidae & Insectivorous & $\mathrm{C} 75$ \\
\hline Green-tailed Sunbird & Aethopyga nipalensis & Passeriformes & Nectariniidae & Frugivorous & $\mathrm{C} 76$ \\
\hline Black-throated Sunbird & Aethopyga saturata & Passeriformes & Nectariniidae & Frugivorous & $\mathrm{C} 77$ \\
\hline Mrs Gould Sunbird & Aethopyga gouldiae & Passeriformes & Nectariniidae & Frugivorous & $\mathrm{C} 78$ \\
\hline Green-backed Tit & Parus monticulus & Passeriformes & Paridae & Omnivorous & C79 \\
\hline Black-lored Tit & Parus xanthogenys & Passeriformes & Paridae & Insectivorous & $\mathrm{C} 80$ \\
\hline Great Tit & Parus major & Passeriformes & Paridae & Insectivorous & $\mathrm{C} 81$ \\
\hline House Sparrow & Passer domesticus & Passeriformes & Passeridae & Frugivorous & $\mathrm{C} 82$ \\
\hline Russet Sparrow & Passer rutilans & Passeriformes & Passeridae & Frugivorous & $\mathrm{C} 83$ \\
\hline Ashy-throated Warbler & Phylloscopus maculipennis & Passeriformes & Phylloscopidae & Insectivorous & $\mathrm{C} 84$ \\
\hline Grey-hooded Warbler & Phylloscopus xanthoschistos & Passeriformes & Phylloscopidae & Insectivorous & $\mathrm{C} 85$ \\
\hline Red-vented Bulbul & Pycnonotus cafer & Passeriformes & Pycnonotidae & Frugivorous & $\mathrm{C} 86$ \\
\hline Black Bulbul & Hypispetes leucocephalus & Passeriformes & Pycnonotidae & Frugivorous & $\mathrm{C} 87$ \\
\hline Himalayan Bulbul & Pycnonotus leucogenys & Passeriformes & Pycnonotidae & Frugivorous & C88 \\
\hline Striated Bulbul & Pycnonotus striatus & Passeriformes & Pycnonotidae & Omnivorous & C89 \\
\hline Mountain Bulbul & Ixos mcclellandii & Passeriformes & Pycnonotidae & Frugivorous & $\mathrm{C} 90$ \\
\hline Grey-sided Bush Warbler & Cettia brunnifrons & Passeriformes & Scotocercidae & Insectivorous & C91 \\
\hline Aberrant Bush Warbler & Cettia flavolivacea & Passeriformes & Scotocercidae & Insectivorous & $\mathrm{C} 92$ \\
\hline Wallcreeper & Tichodroma muraria & Passeriformes & Sittidae & Insectivorous & C93 \\
\hline White-tailed Nuthatch & Sitta himalayensis & Passeriformes & Sittidae & Insectivorous & C94 \\
\hline Common Myna & Acridotheres tristis & Passeriformes & Sturnidae & Omnivorous & $\mathrm{C} 95$ \\
\hline Grey-winged Blackbird & Turdus boulboul & Passeriformes & Turdidae & Insectivorous & C96 \\
\hline Scaly Thrush & Zoothera dauma & Passeriformes & Turdidae & Insectivorous & C97 \\
\hline Orange-headed Thrush & Zoothera citrina & Passeriformes & Turdidae & Insectivorous & C98 \\
\hline Oriental White-eye & Zosterops palpebrosus & Passeriformes & Zosteropidae & Omnivorous & C99 \\
\hline Great Egret & Casmerodius albus & Pelecaniformes & Ardeidae & Carnivorous & $\mathrm{C} 100$ \\
\hline Indian Pond Heron & Ardeola grayii & Pelecaniformes & Ardeidae & Carnivorous & C101 \\
\hline Little Egret & Egretta garzetta & Pelecaniformes & Ardeidae & Carnivorous & $\mathrm{C} 102$ \\
\hline Cattle Egret & Bubulcus ibis & Pelecaniformes & Ardeidae & Insectivorous & $\mathrm{C} 103$ \\
\hline Intermediate Egret & Mesophoyx intermedia & Pelecaniformes & Ardeidae & Carnivorous & C104 \\
\hline Great Barbet & Megalaima virens & Piciformes & Megalaimidae & Frugivorous & $\mathrm{C} 105$ \\
\hline Blue-throated Barbet & Megalaima asiatica & Piciformes & Megalaimidae & Frugivorous & C106 \\
\hline Golden-throated Barbet & Megalaima franklinii & Piciformes & Megalaimidae & Frugivorous & C107 \\
\hline Fulvous-breasted Woodpecker & Dendrocopos macei & Piciformes & Picidae & Insectivorous & C108 \\
\hline Grey-headed Woodpecker & Picus canus & Piciformes & Picidae & Insectivorous & C109 \\
\hline Darjeeling Woodpecker & Dendrocopos darjellensis & Piciformes & Picidae & Insectivorous & C110 \\
\hline Slaty-headed Parakeet & Psittacula himalayana & Psittaciformes & Psittacidae & Frugivorous & C111 \\
\hline Collared Owlet & Glaucidium brodiei & Strigiformes & Strigidae & Carnivorous & C112 \\
\hline
\end{tabular}

